\title{
Role of Notary in the Making of A Powerful Legal Entire Property Distribution Deed
}

\author{
Hawwa Hauro*) and Widayati ${ }^{* *}$ \\ *) Faculty of Law, Universitas Islam Sultan Agung (UNISSULA) Semarang, E-mail: \\ hawwahauro@gmail.com \\ ${ }^{* *)}$ Faculty of Law, Universitas Islam Sultan Agung (UNISSULA) Semarang, E-mail: \\ widayati@unissula.ac.id
}

\begin{abstract}
The distribution of inheritance using a notary deed is an alternative method of inheritance distribution in addition to using court institutions which are commonly used by Indonesian people in inheritance distribution. This writing aims to analyze the theory of the implementation of the distribution of inheritance and the evidentiary process in order to get full evidence in the District Court. The research method used in this thesis is a sociological juridical approach, namely legal research carried out by examining how reactions and interactions occur because legal expectations are often different from the reality that occurs in society, or it can be called the gap between Das Sein (facts) and Das Sollen (norms/expectations). This study was analyzed using the theory of justice in Islam, the theory of legal certainty, and the theory of proof. The results of the study found that the theoretical analysis of the implementation of the distribution of inheritance, both according to the distribution of Islamic inheritance and the Civil Code already has legal certainty. The power of proof attached to an authentic deed is perfect strength and means that the proof is sufficient with the deed itself unless there is opposing evidence (tegen bewijs) which proves otherwise or proves otherwise from the deed. A deed according to the formulation of Article 1868 of the Civil Code, to obtain authenticity as an authentic deed, must meet several requirements, namely: the deed is made by or before a public official; the deed must be made in the form determined by law; and the public official must have the authority to make a deed.
\end{abstract}

Keywords: Notary; Deed; Distribution of Inheritance.

\section{Introduction}

The problem of wealth in society is a very vital factor. No doubt disputes that occur because of disagreements regarding the management of assets. Regarding property itself, it can be in the form of legal events, which we know as inheritance. There is a division of assets due to the death of the heir whose assets will fall to the rightful heirs. 
This other party acts as an intermediary between the first party and the second or more parties. In this case an institution is formed which is known as a notary institution or we are familiar with a notary. As stated in Article 1 paragraph (1) of the Law on Notary Positions, a Notary is a public official authorized to make authentic words and other authorities as referred to in this Law. ${ }^{1}$ This understanding does not mean that the role of the Notary is only in the making of the deed, but if we look at the authority and obligations of the Notary as contained in the Articles of the Notary Position Act, we will understand that in the process the Notary plays an important role in every legal event or action that occurs required by the parties to have the deed fastened by a Notary ${ }^{2}$.

Islamic law also regulates the giving and distribution of assets, namely Islamic inheritance law, wills and grants. In several Islamic law iterations, several terms are found to name Islamic Inheritance Law, such as Fiqh Mawaris, inheritance law and faraid science. ${ }^{3}$

This difference in naming occurs because of the difference in direction which is used as the main point in the discussion. The Compilation of Islamic Law distinguishes between inheritance and inheritance. ${ }^{4}$ The definition of inheritance is contained in Article 1 letter e, namely part of joint property after being used for the needs of the testator during illness until death. The cost of managing the corpse (tajlis). While the definition of inheritance contained in Article letter $d$ is that inheritance is property left by the heir, either in the form of property that is his property or his rights.

The distribution of inheritance using a notary deed is an alternative method of inheritance distribution in addition to using court institutions which are commonly used by Indonesian people in inheritance distribution. Similar to court decisions, the deed made by a notary is intended to explain the distribution of inheritance to anticipate problems that may arise in the future. Based on positive Indonesian law, there are several ways to determine the distribution of inheritance.

In the case of making a notarial deed, it is not necessary to hold accountable the notary because the notary who made the deed and the notary deed is an authentic deed that will prove itself as legal evidence. Because the Notary deed

\footnotetext{
${ }^{1}$ Act No. 2 of 2014 amendments to Act No. 30 of 2004 concerning the Position of Notary

${ }^{2}$ Widyawati, \& Handoko, Widhi. (2018). The Notary Role / PPAT in Improving Legal Awareness Society to Perform Registration Rights to Land Based on Government Regulation No. 24 of 1997 on Land Registration. JURNAL AKTA: Vol. 5, No. 4, 975-980. Retrieved from http://jurnal.unissula.ac.id/index.php/akta/article/view/4127

${ }_{3}$ TM Hasbi As-Shiddiqi, Fiqh Mawaris, (Semarang: Rizki Putra Library, 2001), p.5

${ }^{4}$ Aulia Muthiah, Dynamics of Islamic Law Around Family Law, (Jakarta: New Pustaka, 2017), page 
as an authentic deed must be seen and assessed for what it is so that if there are parties who deny, accuse and/or judge that the Notary deed is fake, then that party will prove it through a civil lawsuit process. ${ }^{5}$

Deed of distribution of inheritance made by a notary can be said to be an authentic deed. An authentic deed has the power of proof as a deed consisting of:

1. The strength of external evidence that the deed itself has the ability to prove itself as an authentic deed as referred to in Article 1875 BW. The power of proof of an authentic deed is not given to a deed made under the hands because for a private deed it has a valid proving power if all who signed the deed have acknowledged the contents of the deed and the parties who signed the underhand deed. While the authentic deed proves itself the validity of the deed in question. The strength of external evidence that a Notary deed is not only binding on the parties who made it. For the interested parties, their heirs and for those who have rights from them,

2. The power of formal proof, this deed proves the truth of what is witnessed, namely what is seen, heard, and done by a Notary as a public official in carrying out his position. ${ }^{6}$

Notary as one of the law enforcers because the Notary makes written evidence that has the power of proof. Legal experts are of the opinion that a Notary deed can be accepted in court as absolute evidence regarding its contents, but even so, a denial can be held with evidence to the contrary by witnesses who can prove that what is explained by a Notary in the deed is true. ${ }^{7}$

Based on the description of the background explaining the deed of inheritance distribution, the authors are interested in studying and researching further by taking the title of the role of a notary in making a legally binding deed of distribution of inheritance.

\section{Research Method}

Researchers use legal research methods with a juridical approachsociological, the research specification used is descriptive analysis, the data source comes from primary data and secondary data. Methods of data collection is done through

\footnotetext{
${ }^{5} \mathrm{Habib}$ Adjie, Bernas - Thoughtful Thoughts in the Field of Notaries and PPAT, (Bandung: Mandar Maju, 2012), p. 14

${ }^{6}$ Lumban Tobing, Notary Position Regulations, (Jakarta: Erlangga, 1992), p. 51

${ }^{7}$ Ngadino, Duties and Responsibilities of Notary Positions in Indonesia, (Semarang: PGRI University Semarang Press, 2019), p. 3
} 
field studies and literature studies. This writing is analyzed qualitatively by using the analytical knife of Islamic justice theory, legal certainty theory, and proof theory.

\section{Results and Discussion}

\subsection{Theory Analysis of the Implementation of the Distribution of Inheritance and the Evidence Process at the Pekalongan District Court}

Inheritance law according to the conception of Western civil law originating from BW, is part of property law. Therefore, only rights and obligations in the form of assets are inherited and will be inherited. Rights and obligations in public law, rights and obligations arising from decency and decency will not be inherited, as well as rights and obligations arising from family law relationships, these also cannot be inherited. Basically the process of transferring one's assets to his heirs, which is called inheritance, occurs only because of death. Therefore, a new inheritance will occur if three conditions are met, namely:

1. There is someone who died.

2. There is a person who is still alive as an heir who will receive an inheritance when the testator dies.

3. There are a number of assets left by the heir.

The characteristics of inheritance law according to BW include "the absolute right of the respective heirs to demand the distribution of the inheritance at any time". ${ }^{9}$ This means that if an heir demands the distribution of the inheritance before the court, the claim cannot be rejected by the other heirs. This provision is stated in Article 1066 BW, namely:

1. A person who has the right to part of the inheritance cannot be forced to give the inheritance in a state that is not divided among the existing heirs.

2. The division of inheritance can always be sued even if there is an agreement that prohibits it.

3. The agreement to postpone the distribution of inheritance can only be done for a certain period of time.

4. The suspension of distribution agreement is only binding for five years, but can be renewed if the parties still desire.

\footnotetext{
${ }^{8}$ Sukarmi \& Ong Argo Victoria. (2018). Cash Waqf in Sustaining Of Indonesian Society "In Legal \& Economic Perspective". AL-ITQAN: Journal of Islamic Sciences: IIUM Malaysia. https://journals.iium.edu.my/al-itqan/index.php/al-itqan/article/view/43

${ }^{9}$ Eman Rohmawan, 2007, Indonesian Inheritance Law, PT. Refika Aditama, Bandung, p.43
} 
Inheritance in the western civil law system originating from BW includes all property along with the rights and obligations of the testator in the field of property law which can be valued in money. Previously, it has been stated that the death of a person according to BW results in the immediate transfer of all matters and obligations to his heirs. This is explicitly stated in Article 833 paragraph (1) BW, namely "all heirs by law obtain ownership rights over all goods, all rights, and all receivables from the deceased". The transfer of rights and obligations from the deceased to the heirs is called "saisine". ${ }^{10}$ As for what is meant by saisine, namely: the heirs obtain all the rights and obligations of the deceased without requiring a certain action, as well as if the heirs do not know about the existence of the inheritance. The BW inheritance system does not recognize the term "original property or gono-gini property" or assets obtained during marriage, because the inheritance in BW from anyone who is a unit that is unanimously and intact in its entirety will pass from the hands of the heirs/heirs to the inheritance his heirs ${ }^{11}$.

Western civil inheritance law is the oldest inheritance law in written form that is enforced in Indonesia because it is based on BW, where BW was enforced in Indonesia in 1848 with the principle of Concordance, meaning that any regulations imposed in the Netherlands are also enforced in the Dutch colonies. including the Dutch East Indies (Indonesia). Second, the division of inheritance in western civil law emphasizes more on giving inheritance rights to families who are blood or married, this is considered more fair then there is equality between the rights of men and women and thirdly, the existence of a method of inheritance distribution can be carried out according to the Ab intestato method that the heirs are people who have blood relations with the heirs or who have marital relations (this is expressly determined by law). And also the distribution of inheritance can be done by testamentair (will) that the heirs have been determined in the will by the heirs. These two methods have their respective advantages and disadvantages for the heirs. The heirs just choose to use the $A b$ Intestato method or the Testamentair method.

In the law there are two ways to get an inheritance, namely as follows: ${ }^{12}$

\section{Ab Intestato (heir according to the law in Article 832 of the Civil Code)}

According to the provisions of the law, those who are entitled to receive a share of the inheritance are blood relatives, both legal and out of wedlock, and the

\footnotetext{
${ }^{10}$ R. Subekti, 1977, Fundamentals of Civil Law, Intermasa, Jakarta, p. 79.

${ }^{11}$ Deen, Thaufiq., Ong Argo Victoria \& Sumain. (2018). Public Notary Services In Malaysia. JURNAL AKTA: Vol. 5, No. 4, 1017-1026. Retrieved from http://jurnal.unissula.ac.id/index.php/akta/article/view/4135

${ }^{12}$ Indah Sari, "Division of Inheritance Rights to Ab Intestato and Testamentair Heirs According to Western Civil Law (BW)", Scientific Journal of Aerospace Law, Vol. 5 No. 1, 2014, p. 6
} 
husband and wife who have lived the longest. Blood families who become heirs are divided into four groups, each of which is the heir of the first, second, third and fourth groups. Regarding this group of heirs, it will be explained further in the discussion of how to divide the rights of heirs according to the Ab Intestato method.

According to this provision, those who are entitled to receive the inheritance share (heirs) are blood relatives, both legal and out of wedlock, and the husband or wife who has lived the longest.

Blood families who become heirs are divided into four groups, each of which is the heir of the first, second, third and fourth groups. Regarding this group of heirs, the author will explain as follows along with how much of each heir receives the inheritance from the heir:

The following is a description of the groups in the division of inheritance according to the Civil Code:

\section{a. Group I}

Husband / wife who lived the longest and their children and descendants (grandchildren)

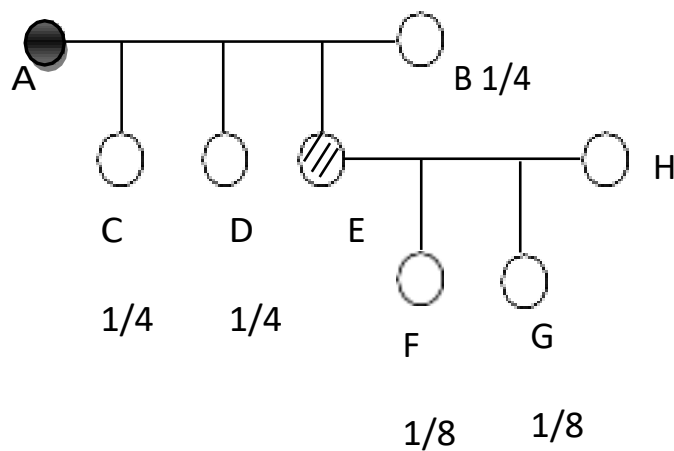

Information:
A : deceased heir (husband)
B : Legal wife A
$C, D, E$ : legitimate children of $A$ and $B$ 
H : Son-in-law and B

F and $\mathrm{G} \quad$ : children $\mathrm{E}$ and $\mathrm{H}$ (grandchildren $\mathrm{A}$ and $\mathrm{B}$ )

E : died before A

b. Group II

Parents (father and mother), siblings and descendants of brothers and sisters

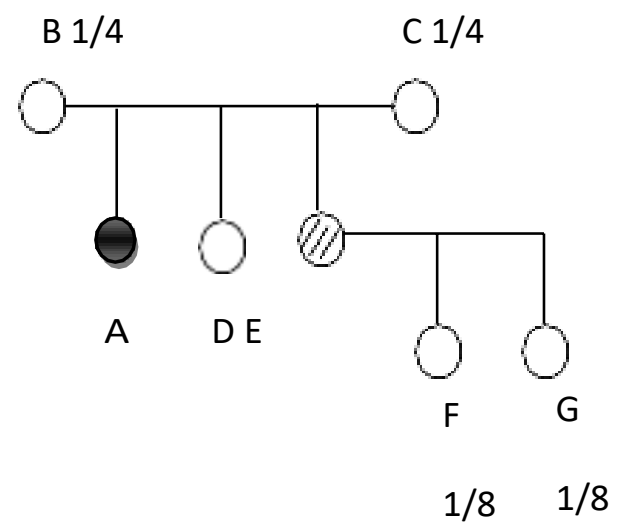

Information:
A
: People who died
B
: biological father of AC: biological mother of $A$
$D$ and $E \quad$ : Siblings of $A$
$F$ and $G \quad$ : Nephew of $A$ or biological child of $E$
E : died before A
c. Group III

Family in a straight line up after father and mother

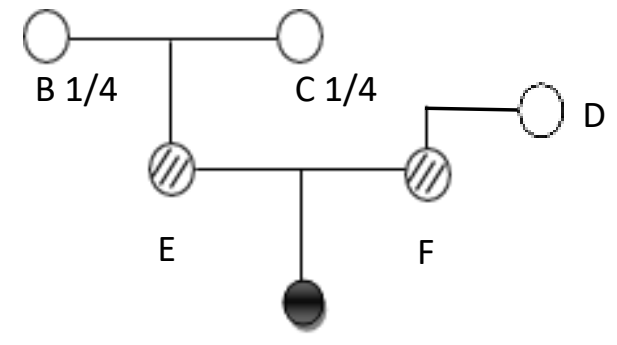

A 
Information:
A: The heir dies B: A's paternal grandfather
C: Grandmother from A from paternal side
D: A's maternal grandmother
E: Father died before $A$
F: mother died before A

\section{d. Group IV}

Side straight line family from the father's side to the sixth degree and side straight line family from the mother's side to the sixth degree.

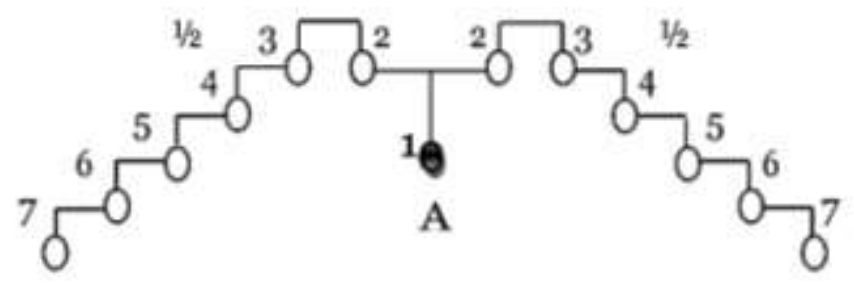

Information:

A: The heir dies, the left side of the straight line from the father's side to the sixth degree and the right side of the straight line from the mother's side to the sixth degree, respectively get a share of the paternal line and from the mother's line $1 / 2$.

There are several things to note in dividing the inheritance in the Ab Intestato way:

a. If these four groups are not present, the inheritance will fall to the state.

b. The former group closes the latter group, so if there are group I heirs, then the group II, III and IV heirs do not become heirs.

c. If group I does not exist, group II will inherit. Groups III and IV do not inherit.

d. Class I includes legitimate and illegitimate children who are recognized as valid without discriminating between men and women and age differences. 
e. If the deceased does not leave offspring, husband or wife, or relatives, the inheritance must be divided into two equal parts, the division is in the form of one part for all blood families in the father's line and one part for all families who are the same in the line. Mother.

Thus, if there are no group I and group II heirs, then the heirs are group III, and if there are no group III heirs, the heir is group IV.

The share for group I heirs is divided equally/ equally for each heir as well as for group II heirs.

For groups III and IV in this case the inheritance is divided equally. Half for the father's bloodline and half for the mother's bloodline.

2. By testamentair (heirs because they are appointed in a will or testament) this is regulated in article 899 of the Civil Code

The distribution of inheritance rights to the heirs testamentally is the distribution by means of a will, where before death the heir makes a will and determines in his will who he wants to be the heir. A will in western civil inheritance law must be made in writing by the testator. Why does it have to be written? This is to guarantee a legal certainty in the distribution of inheritance according to the western civil law method. Then also for definite and clear evidence if later there are parties who are not satisfied with the distribution of the inheritance and can also be used as evidence in court.

Article 857 of the Civil Code provides the following definition of a will: "A will or testament is a deed containing a person's statement about what will happen after he dies, and by him it can be withdrawn". Thus, a testament is a deed, a statement made as evidence with the intervention of an official official.

The involvement of a notary in the implementation of inheritance law can be seen from the provisions currently in force regarding notaries. Provisions specifically regarding notaries are regulated in Law No. 2 of 2014 concerning Notary Positions. The Notary Position Act can be said to be a mandate of the Civil Code, especially in Article 1868.

For the implementation of Article 1868 of the Civil Code, legislators must make laws and regulations to appoint public officials who are authorized to make authentic deeds and therefore notaries are appointed as such officials based on the Law on Notary Positions.

The authority of a notary, according to Article 15 paragraph (1) of the UUJN, a notary is a public official who is authorized to make an authentic deed regarding 
all actions, agreements and provisions required by laws and/or desired by the interested parties to be stated in an authentic deed guaranteeing certainty. the date of making the deed, keeping the deed, providing grosse, copies and quotations of the deed, all of this as long as the making of the deed is not assigned or excluded to other officials as stipulated by law. ${ }^{13}$

In the explanation of the Law on Notary Positions, it is explained the importance of the notary profession, which is related to the making of authentic deeds. Making authentic deeds is required by legislation in the context of certainty, order and legal protection.

An authentic deed made by or before a notary, not only because it is required by laws and regulations, but also because it is desired by interested parties to ensure the rights and obligations of the parties for the sake of certainty, order, and legal protection for interested parties as well as for legal protection. society as a whole.

In the case of making a deed, the Notary does not need to be held accountable because the notary who made the deed and the notary deed is an authentic deed that will prove itself as legal evidence. ${ }^{14}$ Because the Notary deed as an authentic deed must be seen and assessed for what it is so that if there are parties who deny, accuse and/or judge that the Notary deed is fake, then that party will prove it through a civil lawsuit process.

Legal protection for a Notary is not regulated clearly and firmly in a Law, which in Article 66 of the Law on Notary Positions states that for judicial proceedings, investigators, public prosecutors, or judges with the approval of the Regional Supervisory Council are authorized to take a photocopy of the minutes of the deed. and or letters attached to the minutes of the deed or notary protocol in the notary's depository and summoning the notary to attend the examination relating to the deed he made or the notary protocol that is in his custody.

Without the approval of the Regional Supervisory Council, a Notary cannot be held accountable. Therefore, based on the Article, it is still not considered to be able to provide legal protection for a Notary. For that, of course, it must be immediately considered by forming legislation that can provide legal protection and guarantees to a Notary.

\footnotetext{
${ }^{13}$ Habib Adjie. 2012, Bernas - Bernas Thought in the Field of Notaries and PPAT, Mandar Maju, Bandung, p. 14

${ }^{14}$ Interview with Rudi Setyawan, the Main Pranata Judge at the Pekalongan District Court on April 6, 2021
} 
The connection is in making a certificate of inheritance, when the heir wants to make an inheritance letter about what he wants to happen when he dies and the letter has perfect evidentiary power that cannot be disputed by others, then the person comes before a Notary to make an authentic deed. which has perfect proving power.

When the heir comes before a notary with the intention of making an inheritance deed that will take effect after he dies, and when the inheritance deed is opened and read before the heirs, this is where the dispute begins. At the time of reading the contents of the inheritance deed, when there are heirs who feel that they do not benefit from the contents of the inheritance deed, they file a lawsuit for cancellation of the contents of the deed, in which the heirs deny that the signature in the notary deed is not the original signature of the heir, because it is deemed unfavorable to the heir based on the legitime fortie. Therefore, if this dispute continues and the notary is held accountable for the authenticity of the deed made by him, therefore as a public official authorized in the matter of making the deed, ${ }^{15}$

The distribution of inheritance based on the Civil Code is clear and understandable when it comes to distributing inheritance. The Civil Code has set out in detail and detail about who is entitled to receive inheritance and parts thereof. This has provided legal certainty for people who will carry out the distribution of inheritance. Legal certainty as one of the objectives of the law can be said as part of efforts to realize justice. The real form of legal certainty is the implementation or enforcement of the law against an action regardless of who does it. With legal certainty, everyone can predict what will be experienced if they take certain legal actions. Certainty is needed to realize the principle of equality before the law without discrimination.

Gustav Radbruch put forward 4 (four) basic things related to the meaning of legal certainty, namely:

a. First, that the law is positive, meaning that the positive law is legislation.

b. Second, that the law is based on facts, meaning that it is based on reality.

c. Third, that the facts must be formulated in a clear way so as to avoid mistakes in meaning, as well as being easy to implement.

d. Fourth, positive law should not be easily changed.

Inheritance law according to Islamic law as a part of family law (Al ahwalus Syahsiyah) is very important to learn so that in the implementation of the

\footnotetext{
${ }^{15}$ Setya Qodar Al-Haolandi, et al, "The Role of Notaries in the Distribution of Inheritance Based on Western Inheritance Rights with the Role of Religious Courts in the Distribution of Inheritance Based on Islamic Inheritance Rights", Journal of Deed, Vol. 5 No. 1, 2018, p. 123
} 
distribution of inheritance there are no mistakes and can be carried out in the fairest way possible, because by studying Islamic inheritance law, for Muslims, it will can fulfill the rights relating to the inheritance after being left by the muwarris (heir) and delivered to the heirs who are entitled to receive it. Thus a person can avoid the sin of not eating people's property that is not their right, because the Islamic law regarding inheritance is not fulfilled. This is further confirmed by the Prophet Muhammad. Which means:

"Learn the Qur'an and teach it to people, and learn faraid and teach it to people, for verily I am one who will die, and knowledge will be raised, and there may be two people dispute, but they will not meet someone who will tell HR. Ahmad Turmudzi and An Nasa'l".

Based on the hadith mentioned above, the knowledge of inheritance according to Islam is very important, especially for Islamic law enforcers it is absolute, so that it can fulfill the expectations stated in the hadith of the Prophet Muhammad above.

The theory of justice according to Islam, fair means paying attention to individual rights and giving those rights to each owner. Fair in this case can be defined as wadh al-syai' fi mahallihi (putting something in its place). The opposite is zalim, namely wadh' al-syai' fi ghairi mahallihi (putting something out of place). The division of inheritance, both according to the Civil Code and the Compilation of Islamic Law, has put something in its place. His inheritance has been regulated and divided as stated in the provisions of the legislation.

\subsection{Making a Deed To Get Full Evidence}

Proof is a stage that has an important role for judges to make a decision. The process of proof in the trial process can be said to be the center of the examination process in court. Proof becomes central because the arguments of the parties are tested through the evidentiary stage in order to find the law to be applied (rechtoepasing) or discovered (rechtvinding) in a particular case. Evidence is historical, which means that this proof tries to determine what events have occurred in the past which are currently considered as truth, events that must be proven are relevant events, because irrelevant events do not need to be proven. ${ }^{16}$

The law of proof is needed for the creation of legal certainty, besides that the law of proof is also needed to prevent the emergence of vigilante acts between litigants, especially in defending the truth of the rights they have in court.

${ }^{16}$ Subekti, 2001, Law of Evidence, Pradnya Paramita, Jakarta, p. 33 
Therefore, this evidence is a very important part in the examination of cases in court.

The legal system of evidence adopted in Indonesia is a closed and limited system in which the parties are not free to submit types or forms of evidence in the case settlement process. The law has clearly determined what is legal and valuable as evidence. Restrictions on freedom also apply to judges where the judge is not free and is free to accept whatever the parties propose as evidence. If the litigating party submits evidence outside the provisions in the law that regulates it, the judge must refuse and set it aside in the settlement of the case.

Evidence (bewijsmiddel) of various forms and types, which are able to provide information and explanations about the problems being litigated in court. The evidence is submitted by the parties to justify the argument of the lawsuit or the argument of rebuttal. In the civil case process, of the five pieces of evidence that can be submitted, written evidence is the preferred evidence, because of the characteristics of civil cases and the formal nature of civil law actions. All formal legal actions as outlined in writing that are carried out clearly and concretely in order to realize the civil procedural law as stipulated in the Civil Code and to provide legal force to guarantee the rights of a person. ${ }^{17}$

Written evidence or letters are anything that contains reading signs that are intended to pour out one's heart or convey one's thoughts and are used as evidence. Letter as written evidence is divided into two, namely a letter which is a deed and another letter that is not a deed, a deed is a letter as evidence that is signed, which contains events that form the basis of a right and an agreement, which was made from the start intentionally for proof, must the signing of a letter to be referred to as a deed is regulated in Article 1886 of the Civil Code. The signature is nothing but the purpose of distinguishing one deed from another or a deed made by another person, to characterize it. ${ }^{18}$

Deed according to its form is divided into authentic deed and deed under the hand. An authentic deed is a deed whose form is determined by law and made by or before an official authorized to make the deed. Authentic deeds are further divided into official deed (acte ambtelijk) and deed of the parties (partiacte), official deed (acte ambtelijk) is a deed whose initiative is made by the official not based on the initiative of the parties listed in the deed, while the deed of the parties (partiacte) is a deed whose initiative is made by the parties who come before an official such as a deed of power of attorney, a deed of land ownership

\footnotetext{
${ }^{17}$ M. Natsir Asnawi, 2013, Law of Evidence for Civil Cases in Indonesia, UII Press, Yogyakarta, p. 31

${ }^{18}$ Ibid, p. 32
} 
rights and a deed of sale and purchase which is usually made before a Notary Official, also known as a notarial deed. ${ }^{19}$

The power of proof attached to an authentic deed is perfect strength and means that the proof is sufficient with the deed itself unless there is evidence against it (tegen bewijs) which proves otherwise or proves otherwise from the deed, the word binding means the judge is bound by the deed itself as long as the deed is made in accordance with the legal provisions of a deed as regulated in Article 1886 of the Civil Code.

Authentic deed as evidence that is considered the strongest and most complete. Establishing a clear legal relationship between the parties regarding rights and obligations, the deed itself is made to ensure legal certainty and in order to avoid disputes in the future. One of the authorities to make this authentic deed lies with the Notary Officer, as stated in Article 1 UUJN No. 2 of 2014 concerning amendments to UUJN No. 30 of 2004, namely Notary is a public official who has the authority to make authentic deeds and other authorities as referred to in the Act, which is then explained further in Article 15 UUJN No. 2 of 2014 concerning amendments to UUJN No. 30 of 2004.

Authentic deeds that can be used as evidence can be divided into:

1. Deeds that must be made before a notary, such as the establishment of a Limited Liability Company, deed of grant, deed of inheritance distribution, deed of fiduciary, deed of foundation and so on.

2. Deed whose authority lies with a notary or other officials;

a. deed of acknowledgment of children out of wedlock, may be by notarial deed, may also be by deed made by civil registry officer.

b. an offer to pay debts in cash to debtors can be made by a notarial deed or by a bailiff deed. Such an application is made if the debtor is not available, while the time for payment is due.

c. non-acceptance protest and non-payment protest. Deeds that can only be made by other officials are not notaries, marriage certificates, birth certificates, divorce certificates, marriage license certificates, death certificates.

A deed, according to the formulation of Article 1868 of the Civil Code, to obtain authenticity as an authentic deed, must meet several requirements, namely:

${ }^{19}$ Ropaun Rambe, 2010, Complete Civil Procedure Law, Sinar Graphic, Jakarta, p. 42 
1. deed made by or before a public official;

2. the deed must be made in the form determined by law;

3. The public official must have the authority to make a deed.

\section{Closing}

The notary must have proper control in the making of the inheritance distribution deed regarding the duties and authorities of the notary. Accuracy and completeness of knowledge regarding inheritance law should be properly controlled by a Notary so that there are no mistakes in making the deed considering that inheritance is one of the conflictual laws considering that its contents in the form of property and assets in this materialistic era play an important role for human survival in the future. This is to minimize notary errors which may not be brought to court by the parties concerned. Therefore, before it's too late, the Notary must prepare everything carefully and know the inheritance law that applies in Indonesia.

\section{References}

Journals:

[1] Indah Sari, "Pembagian Hak Waris Kepada Ahli Waris Ab Intestato dan Testamentair Menurut Hukum Perdata Barat (BW)", Jurnal IImiah Hukum Dirgantara, Vol. 5 No. 1, 2014.

[2] Setya Qodar Al-Haolandi, dkk, "Peran Notaris dalam Pembagian Waris Berdasarkan Hak Waris Barat Dengan Peran Pengadilan Agama dalam Pembagian Waris Berdasarkan Hak Waris Islam", Jurnal Akta, Vol. 5 No. 1, 2018.

[3] Deen, Thaufiq., Ong Argo Victoria \& Sumain. (2018). Public Notary Services In Malaysia. JURNAL AKTA: Vol. 5, No. 4, 1017-1026. Retrieved from http://jurnal.unissula.ac.id/index.php/akta/article/view/4135

[4] Sukarmi \& Ong Argo Victoria. (2018). Cash Waqf in Sustaining of Indonesian Society "In Legal \& Economic Perspective". AL-ITQAN: Journal of Islamic Sciences: IIUM Malaysia. https://journals.iium.edu.my/alitqan/index.php/al-itqan/article/view/43

[5] Widyawati, \& Handoko, Widhi. (2018). The Notary Role / PPAT in Improving Legal Awareness Society to Perform Registration Rights to Land Based on Government Regulation No. 24 of 1997 on Land Registration. JURNAL AKTA: Vol. 5, No. 4, 975-980. Retrieved from http://jurnal.unissula.ac.id/index.php/akta/article/view/4127 
Books:

[1] Aulia Muthiah, 2017, Hukum Islam Dinamika Seputar Hukum Keluarga, Pustaka Baru, Jakarta.

[2] Eman Rohmawan, 2007, Hukum Waris Indonesia, PT. Refika Aditama, Bandung.

[3] Habib Adjie, 2012, Bernas - Bernas Pemikiran Di Bidang Notaris Dan PPAT, Mandar Maju, Bandung.

[4] Lumban Tobing, 1992, Peraturan Jabatan Notaris, Erlangga, Jakarta.

[5] M. Natsir Asnawi, 2013, Hukum Pembuktian Perkara Perdata di Indonesia, UII Press, Yogyakarta.

[6] Ngadino, 2019, Tugas dan Tanggung Jawab Jabatan Notaris di Indonesia, Universitas PGRI Semarang Press, Semarang.

[7] R. Subekti, 1977, Pokok-pokok Hukum Perdata, Intermasa, Jakarta.

[8] Ropaun Rambe, 2010, Hukum Acara Perdata Lengkap, Sinar Grafika, Jakarta.

[9] Subekti, 2001, Hukum Pembuktian, Pradnya Paramita, Jakarta.

[10] T.M Hasbi As-Shiddiqi, 2001, Fiqih Mawaris, Pustaka Rizki Putra, Semarang. 